\title{
Dry Matter Production and Nutrient Uptake of Rice (Oryza sativa L.) Varieties under Alternate Wetting and Drying in Puddled Soil
}

\author{
M. Sharath Chandra ${ }^{*}$, K. Avil Kumar ${ }^{2}$, M. Madhavi ${ }^{3}$ and D. Srinivasa Chary ${ }^{4}$
}

Water Technology Centre, College of Agriculture, Professor Jayashanakar Telangana State Agricultural University, Rajendranagar, Hyderabad - 500030

*Corresponding author:

\section{A B S T R A C T}

\begin{tabular}{|l|}
\hline Ke y w or d s \\
AWD- alternate \\
wetting and drying, \\
$\begin{array}{l}\text { Rice varieties, Dry } \\
\text { matter production, } \\
\text { Nutrient uptake }\end{array}$ \\
\hline Article Info \\
\hline $\begin{array}{l}\text { Accepted: } \\
\text { 20 July 2019 } \\
\text { Available Online: } \\
\text { 10 August } 2019\end{array}$ \\
\hline \hline
\end{tabular}

A field experiment was conducted on sandy clay soil at Agricultural College farm, PJTSAU, Rajendranagar, Hyderabad during kharif, 2016 in a split plot design with three replications. The treatments comprised of three irrigation regimes (irrigation of $5 \mathrm{~cm}$ when water level falls below $5 \mathrm{~cm}$ from soil surface in field water tube, irrigation of $5 \mathrm{~cm}$, at one day after disappearance of water on the surface of the soil and recommended submergence of 2-5 cm water level as per crop stage) as main treatments and four rice varieties (Telangana sona, Kunnaram sannalu, Bathukamma and Sheethal) as sub plots treatments. The data recorded indicated that recommended submergence of $2-5 \mathrm{~cm}$ water level as per crop stage recorded higher dry matter and $\mathrm{N}, \mathrm{P}$ and $\mathrm{K}$ uptake over AWDI of $5 \mathrm{~cm}$ when water falls below $5 \mathrm{~cm}$ from soil surface in field water tube and was on par with AWDI of $5 \mathrm{~cm}$ at one DADSW. Bathukamma produced higher dry matter and N P K uptake compared to Kunaram Sannalu, Sheethal and Telangana Sona. Based on the results it can be concluded that Bathukamma recorded higher dry matter and $\mathrm{N}, \mathrm{P}$ and $\mathrm{K}$ uptake under recommended submergence of $2-5 \mathrm{~cm}$ water level as per crop stage.

\section{Introduction}

Rice (Oryza sativa L.) is the most important staple in Asia with about $75 \%$ of the global rice volume is produced in the irrigated lowlands [Maclean et al., 2002]. Rice production in Asia is increasingly constrained by water limitation [Arora, 2006] and increasing pressure to reduce water use in irrigated production as a consequence of global water crisis [Tuong and Bouman, 2002]. Decreasing water availability for agriculture threatens the productivity of the irrigated rice ecosystem and ways must be sought to save water and increase the water productivity of rice [Guerra et al.,1998]. Conventional water management in lowland rice aims at keeping the fields continuously submerged. Water inputs can be reduced and water productivity increased by introducing periods of no submerged conditions of several days throughout the growing season until cracks are formed through the plough sole [Bouman and Tuong, 2001]. Water saving is 
the main issue in maintaining the sustainability of rice production when water resources are becoming scarce [Arif et al.,2012]. In Asia, with relatively more suitable growing conditions for rice, production has declined due to increasing water stress [Aggarwal, 2000; Tao, 2004]. There are a number of alternatives to continuous flooding of rice. One of the most commonly practiced WSI techniques is alternate wetting and drying irrigation [Kumar et al., 2014].

\section{Materials and Methods}

A field experiment was conducted on sandy clay soil at Agricultural College farm (17 32 ' $\mathrm{N}$ Latitude, $78^{\circ} 40^{\prime} \mathrm{E}$ Longitude and at 542.6 $\mathrm{m}$ above mean sea level), Rajendranagar, Hyderabad during kharif, 2016. in a split plot design with three replications. The seedlings of different rice varieties at 21days age old were transplanted by adopting a spacing of 15 $\times 15 \mathrm{~cm}$. The recommended dose of 120:60:40 N, $\mathrm{P}_{2} \mathrm{O}_{5}$ and $\mathrm{K}_{2} \mathrm{O} \mathrm{kg} \mathrm{ha}{ }^{-1}$ was applied. The experimental soil was sandy clay in texture, moderately alkaline in reaction, non-saline, low in organic carbon content, low in available nitrogen ( $\mathrm{N}-244.8 \mathrm{Kg} \mathrm{ha}{ }^{-1}$ ), medium in available phosphorous $\left(\mathrm{P}_{2} \mathrm{O}_{5^{-}} 56.3\right.$ $\left.\mathrm{Kg} \mathrm{ha}^{-1}\right)$ and potassium $\left(\mathrm{K}_{2} \mathrm{O}-230.7 \mathrm{Kg} \mathrm{ha}^{-1}\right)$. The treatments combination include three irrigation regimes $\left(\mathrm{I}_{1}\right.$-irrigation of $5 \mathrm{~cm}$ when water level falls below $5 \mathrm{~cm}$ from soil surface in field water tube, $\mathrm{I}_{2^{-}}$irrigation of $5 \mathrm{~cm}$, at one day after disappearance of water on the surface of the soil and $\mathrm{I}_{3^{-}}$recommended submergence of $2-5 \mathrm{~cm}$ water level as per crop stage) as main treatments and four rice varieties $\left(\mathrm{V}_{1^{-}}\right.$Telangana sona, $\mathrm{V}_{2^{-}}$Kunnaram sannalu, $\mathrm{V}_{3^{-}}$Bathukamma and $\mathrm{V}_{4^{-}}$Sheethal) as sub plots treatments respectively. The experimental plot size was $6 \mathrm{~m} \times 4.2 \mathrm{~m}$. The data recorded, analysed and tabulated after statistical test.

\section{Results and Discussion}

Dry matter production $\left(\mathrm{m}^{-2}\right)$ at various crop growth sub-periods of rice was significantly influenced by differed irrigation regimes except at 30 DAT (Table 1) and among the different irrigation regimes, recommended submergence of $2-5 \mathrm{~cm}$ water level as per crop stage $\left(\mathrm{I}_{3}\right)$ recorded significantly higher dry matter production $\left(0.88 \mathrm{~kg} \mathrm{~m}^{-2}\right)$ than AWDI of $5 \mathrm{~cm}$ irrigation when water level falls $5 \mathrm{~cm}$ below in the field water tube $\left(\mathrm{I}_{1}\right)$ and was on par with AWDI of $5 \mathrm{~cm}$ one day after disappearance of ponded water $\left(\mathrm{I}_{2}\right)$. However lower dry matter production were obtained with AWDI of $5 \mathrm{~cm}$ submergence water level falls $5 \mathrm{~cm}$ below in the field water tube $\left(\mathrm{I}_{1}, 0.79 \mathrm{~kg} \mathrm{~m}^{-2}\right)$ and was on par with the AWDI of $5 \mathrm{~cm}$ one day after disappearance of ponded water $\left(\mathrm{I}_{2}, 0.83 \mathrm{~kg} \mathrm{~m}^{-2}\right)$ at 60 DAT. Significantly higher dry matter production (1.38 and $1.50 \mathrm{~kg} \mathrm{~m}^{-2}$ ) registered under recommended submergence of $2-5 \mathrm{~cm}$ water level as per crop stage $\left(\mathrm{I}_{3}\right)$ than AWDI of 5 $\mathrm{cm}$ at one day after disappearance of ponded water $\left(\mathrm{I}_{2}, 1.26\right.$ and $1.35 \mathrm{~kg} \mathrm{~m}^{-2}$ respectively) and AWDI of $5 \mathrm{~cm}$ irrigation when water level falls $5 \mathrm{~cm}$ below in the field water tube $\left(\mathrm{I}_{1}\right)$ at 90 DAT and harvest. Ssignificantly lower yield was obtained with AWDI of $5 \mathrm{~cm}$ submergence water level falls $5 \mathrm{~cm}$ below in the field water tube $\left(\mathrm{I}_{1}, 1.08\right.$ and $1.18 \mathrm{~kg} \mathrm{~m}^{-2}$ respectively) at 90DAT and harvest. In the present investigation, consequence of favorable growing environment, better uptake of nutrients helped the plants to boost their growth leading to produce more tillers and pronounced growth characters through supply of more synthates towards sink lead to production of higher dry matter under AWDI of $5 \mathrm{~cm}$ one day after disappearance of ponded water and recommended submergence of 2-5 $\mathrm{cm}$ water level as per crop stage compared to AWDI of $5 \mathrm{~cm}$ submergence depth when 5 $\mathrm{cm}$ drop of water level in the field tube. Similar results of increased dry matter under 
AWDI of $5 \mathrm{~cm}$ at one day after disappearance of ponded water and recommended submergence of $2-5 \mathrm{~cm}$ water level as per crop stage were reported Kumar et al., (2014) and Chowdhury et al., (2014).

Among the varieties, Bathukamma (0.26, 0.85 and $1.30 \mathrm{~kg} \mathrm{~m}^{-2}$ respectively), Kunaram Sannalu (0.26, 0.87 and $1.25 \quad \mathrm{~kg} \mathrm{~m}^{-2}$ respectively) and Sheethal (0.28, 0.84 and $1.23 \mathrm{~kg} \mathrm{~m}^{-2}$ respectively) recorded on par dry matter production at 30,60 and 90 DAT, and were significantly higher dry matter production than Telangana Sona. At 30 DAT Sheethal recorded significantly higher dry matter than Telangana Sona, though on par with other two varieties of Bathukamma and Kunaram Sannalu. Bathukamma recorded significantly higher dry matter at 90 DAT than Telangana Sona and was on par with Kunaram Sannalu. At harvest, Bathukamma recorded significantly higher dry matter production $\left(1.42 \mathrm{~kg} \mathrm{~m}^{-2}\right)$ than rest of the varieties viz., Kunaram Sannalu $\left(1.35 \mathrm{~kg} \mathrm{~m}^{-2}\right)$, Sheethal $\left(1.32 \mathrm{~kg} \mathrm{~m}^{-2}\right)$ and Telangana Sona $\left(1.27 \mathrm{~kg} \mathrm{~m}^{-2}\right)$. Lower dry matter production was recorded with Telangana Sona at 30,60,90 DAT and harvest than other varieties and was significantly lower than all other varieties at 60 DAT, than Bathukamma at 90 DAT and harvest though on par with the same at 30 DAT (Fig 1). Telangana Sona was on par in dry matter production with Kunaram Sannalu at 30 DAT and 90 DAT and with Sheethal at 90 DAT and harvest. Variation in dry matter production among varieties and lower of Telangana Sona might be due to genetically inherent character of the varieties.

\section{Nitrogen uptake}

$\mathrm{N}$ uptake was significantly influenced by different irrigation regimes except at 30 DAT (Table 2) and recommended submergence of $2-5 \mathrm{~cm}$ water level as per crop stage $\left(\mathrm{I}_{3}\right)$ recorded significantly higher $\mathrm{N}$ uptake (37.6,
113.2 and $51.1 \mathrm{~kg} \mathrm{ha}^{-1}$ ) than AWDI of $5 \mathrm{~cm}$ irrigation when water level falls $5 \mathrm{~cm}$ below in the field water tube $\left(\mathrm{I}_{1}\right)$ and was on par with AWDI of $5 \mathrm{~cm}$ at one day after disappearance of ponded water $\left(\mathrm{I}_{2}\right)$ at 60 and 90 DAT and grain at harvest. However lower $\mathrm{N}$ uptake were obtained with AWDI of $5 \mathrm{~cm}$ submergence water level falls $5 \mathrm{~cm}\left(\mathrm{I}_{1}\right)$ below surface in the field water tube $(33.1,88.0$ and $48.0 \mathrm{~kg} \mathrm{ha}^{-1}$ ) and was on par with the AWDI of $5 \mathrm{~cm}$ at one day after disappearance $\left(\mathrm{I}_{2}\right)$ of ponded water $\left(35.0,103.0\right.$ and $\left.49.6 \mathrm{~kg} \mathrm{ha}^{-1}\right)$ at 60 and 90 DAT and by grain at harvest, respectively. Significantly higher N uptake registered with recommended submergence of $2-5 \mathrm{~cm}$ water level as per crop stage $\left(\mathrm{I}_{3}, 62.1\right.$ and $113.2 \mathrm{~kg} \mathrm{ha}^{-1}$ respectively) over AWDI of $5 \mathrm{~cm}$ at one day after disappearance of ponded water $\left(\mathrm{I}_{2}\right)$ and AWDI of $5 \mathrm{~cm}$ irrigation when water level falls $5 \mathrm{~cm}$ below surface in the field water tube $\left(\mathrm{I}_{1}\right)$ by straw and total $\mathrm{N}$ at harvest, respectively. Significantly lower $\mathrm{N}$ uptake recorded with AWDI of $5 \mathrm{~cm}$ irrigation when water level falls $5 \mathrm{~cm}$ below surface in the field water tube $\left(\mathrm{I}_{1}, 41.6,89.6 \mathrm{~kg} \mathrm{ha}^{-1}\right.$ respectively) than AWDI of $5 \mathrm{~cm}$ at one day after disappearance of ponded water $\left(\mathrm{I}_{2}, 53.3\right.$ and $102.9 \mathrm{~kg} \mathrm{ha}^{-1}$, respectively) by straw and total uptake of $\mathrm{N}$ at harvest. Significantly higher N uptake might be due to the greater and healthy root growth, which increased availability and efficient absorption from the soil and transport of nutrients from root to shoot and grains with irrigation at recommended submergence of 2$5 \mathrm{~cm}$ water level as per crop stage $\left(\mathrm{I}_{3}\right)$ compared to irrigation of $5 \mathrm{~cm}$, when water level falls below $5 \mathrm{~cm}$ from soil surface in field water tube. Similar results were observed by Panda et al., (1997), Ramakrishna (2007) and Chowdhury et al., (2014).

Sheethal $\left(6.4 \mathrm{~kg} \mathrm{ha}^{-1}\right)$ among the varieties recorded significantly higher $\mathrm{N}$ uptake than Kunaram Sannalu (5.5 kg ha ${ }^{-1}$ ) and Telangana 
Sona (4.8 $\mathrm{kg} \mathrm{ha}^{-1}$ respectively) at $30 \mathrm{DAT}$ and was on par with Bathukamma. However Bathukamma and Kunaram Sannalu were at par N uptake at 30 DAT, Sheethal and Kunaram Sannalu were at par at 90 DAT and in straw and total $\mathrm{N}$ uptake at harvest and also Kunaram Sannalu and Telangana Sona were at par in $\mathrm{N}$ uptake at 30 and 90 DAT and by straw at harvest. Uptake of $\mathrm{N}$ at $60 \mathrm{DAT}$ by Sheetal, Bathukamma and Kunaram Sannalu (36.9, 36.8 and $35.5 \mathrm{~kg} \mathrm{ha}^{-1}$. respectively was on par and significantly higher than Telangana Sona. At 90 DAT, Bathukamma $\left(107.9 \mathrm{~kg} \mathrm{ha}^{-1}\right)$ recorded $\mathrm{N}$ uptake significantly higher than Telangana Sona (94.4 $\mathrm{kg} \mathrm{ha}^{-1}$ ) and Kunaram Sannalu 101.4 and was on par with Seethal $\left(101.8 \mathrm{~kg} \mathrm{ha}^{-1}\right)$. Significantly lower N uptake was found with Telangana Sona at 30, 60, 90 DAT and by grain and straw and total at harvest then other varieties, through on par with kunaram Sannalu. Bathukamma (53.2 $\mathrm{kg} \mathrm{ha}^{-1}$ ) recorded significantly higher $\mathrm{N}$ uptake in grain at harvest than Telangana Sona $\left(47.0 \mathrm{~kg} \mathrm{ha}^{-1}\right)$, Sheethal (46.9 kg ha ${ }^{-1}$ ) and was on par with Kunaram Sannalu $\left(51.2 \mathrm{~kg} \mathrm{ha}^{-1}\right)$. At harvest Bathukamma (108.8 $\left.\mathrm{kg} \quad \mathrm{ha}^{-1}\right)$ recorded significantly higher total uptake of $\mathrm{N}$ than Kunaram Sannalu (101.9 $\mathrm{kg} \mathrm{ha}^{-1}$ ), Sheethal $\left(101.2 \mathrm{~kg} \mathrm{ha}^{-1}\right)$ and Telangana Sona $(95.7 \mathrm{~kg}$ $\mathrm{ha}^{-1}$ ) though Kunaram Sannalu and Sheethal were on par to each other. Significantly lower $\mathrm{N}$ uptake was found with Telangana Sona at 30, 60, 90 DAT and total at harvest might be due to genetical inherent character of the variety to produce lower dry matter production.

The interaction effect between varieties and irrigation regimes was significant on total $\mathrm{N}$ uptake at harvest (Table 3). The perusal of data indicate that significantly lower uptake of $\mathrm{N}$ was in combination of AWDI of $5 \mathrm{~cm}$, when water level falls below $5 \mathrm{~cm}$ from soil surface in perforated pipe and Telangana Sona $\left(I_{1} \times V_{1}\right)$ than rest of the varieties and irrigation regimes except AWDI of $5 \mathrm{~cm}$, when water level falls below $5 \mathrm{~cm}$ from soil surface in perforated pipe and Kunaram Sannalu $\left(\mathrm{I}_{1} \times \mathrm{V}_{2}\right)$ and AWDI of $5 \mathrm{~cm}$, when water level falls below $5 \mathrm{~cm}$ from soil surface in perforated pipe and Sheethal $\left(\mathrm{I}_{1} \times \mathrm{V}_{4}\right)$. Bathukamma under recommended submergence of $2-5 \mathrm{~cm}$ water level as per crop stage recorded significantly higher $\mathrm{N}$ uptake and was on par with Sheethal at AWDI of $5 \mathrm{~cm}$, when water level falls below $5 \mathrm{~cm}$ from soil surface in perforated pipe $\left(\mathrm{I}_{1}\right)$ and AWDI of $5 \mathrm{~cm}$ at one day after disappearance of ponded water $\left(\mathrm{I}_{2}\right)$ while at recommended submergence of $2-5 \mathrm{~cm}$ water level as per crop stage $\left(I_{3}\right)$ it was on par with Kunaram Sannalu.

\section{Phosphorous uptake}

Different rice varieties were differed significantly on P uptake at 30, 60, 90 DAT and harvest stages of crop growth (Table 4). However, P uptake was not significantly influenced by the interaction effect between different rice varieties and irrigation regimes.

P uptake was significantly influenced by different irrigation regimes at harvest and the differences were not significant at 30,60 and 90 DAT (Table 4) and recommended submergence of $2-5 \mathrm{~cm}$ water level as per crop stage $\left(I_{3}\right)$ recorded significantly higher $P$ uptake (17.36 and $35.13 \mathrm{~kg} \mathrm{ha}^{-1}$ ) over AWDI of $5 \mathrm{~cm}$ at one day after disappearance of ponded water $\left(\mathrm{I}_{2}, 15.15\right.$ and $\left.30.75 \mathrm{~kg} \mathrm{ha}^{-1}\right)$ and AWDI of $5 \mathrm{~cm}$ irrigation when water level falls $5 \mathrm{~cm}$ below in the field water tube $\left(\mathrm{I}_{1}, 15.17\right.$ and $\left.27.21 \mathrm{~kg} \mathrm{ha}^{-1}\right)$ in grain and total at harvest. However, AWDI of $5 \mathrm{~cm}$ at one day at after disappearance of ponded water $\left(\mathrm{I}_{2}\right)$ and AWDI of $5 \mathrm{~cm}$ irrigation when water level falls $5 \mathrm{~cm}$ below in the field water tube $\left(\mathrm{I}_{1}\right)$ were on par to each other in grain at harvest. 
Table.1 Dry matter accumulation of rice varieties $\left(\mathrm{kg} \mathrm{m}^{-2}\right)$ at different growth intervals as influenced by different irrigation regimes

\begin{tabular}{|c|c|c|c|c|}
\hline Treatment & 30 DAT & 60DAT & 90DAT & $\begin{array}{c}\text { At } \\
\text { harvest }\end{array}$ \\
\hline \multicolumn{5}{|l|}{ Main plot-(Irrigation regimes) } \\
\hline $\begin{array}{l}\text { I }_{1} \text { : AWDI of } 5 \mathrm{~cm} \text {, when water level falls below } 5 \mathrm{~cm} \text { from } \\
\text { soil surface in perforated pipe. }\end{array}$ & 0.25 & 0.79 & 1.08 & 1.18 \\
\hline $\begin{array}{l}I_{2}: \text { AWDI of } 5 \mathrm{~cm} \text {, one day after disappearance of ponded } \\
\text { water on the surface of the soil. }\end{array}$ & 0.26 & 0.83 & 1.26 & 1.35 \\
\hline $\begin{array}{l}\text { I }: \text { Recommended submergence of } 2-5 \mathrm{~cm} \text { water level as per } \\
\text { crop stage. }\end{array}$ & 0.27 & 0.88 & 1.38 & 1.50 \\
\hline $\mathrm{SEm} \pm$ & 0.01 & 0.01 & 0.03 & 0.02 \\
\hline C.D $(P=0.05)$ & NS & 0.06 & 0.11 & 0.09 \\
\hline \multicolumn{5}{|l|}{ Sub plot- (Varieties) } \\
\hline$V_{1}-$ RNR 15048 (Telangana sona) & 0.23 & 0.78 & 1.17 & 1.27 \\
\hline $\mathrm{V}_{2}-\mathrm{KNM} 118$ (Kunaram sannalu) & 0.26 & 0.87 & 1.25 & 1.35 \\
\hline 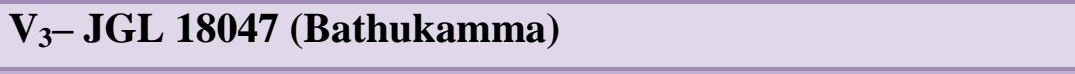 & 0.26 & 0.85 & 1.30 & 1.42 \\
\hline V $_{4}-$ WGL 283 (Sheethal) & 0.28 & 0.84 & 1.23 & 1.32 \\
\hline SEm \pm & 0.01 & 0.02 & 0.03 & 0.02 \\
\hline C.D $(P=0.05)$ & 0.03 & 0.05 & 0.08 & 0.05 \\
\hline \multicolumn{5}{|l|}{ Interaction } \\
\hline \multicolumn{5}{|l|}{ Rice varieties at same level of Irrigation regimes } \\
\hline SEm \pm & 0.02 & 0.03 & 0.05 & 0.03 \\
\hline C.D $(\bar{P}=0.05)$ & NS & NS & NS & NS \\
\hline \multicolumn{5}{|l|}{ Irrigation regimes at same or different levels of rice varieties } \\
\hline $\mathrm{SEm} \pm$ & 0.02 & 0.03 & 0.05 & 0.03 \\
\hline C.D $(P=0.05)$ & NS & NS & NS & NS \\
\hline
\end{tabular}

DAT: Days after Transplanting, AWDI: Alternate wetting and drying irrigation, NS: Non Significant 
Table. 2 Nitrogen uptake $\left(\mathrm{kg} \mathrm{ha}^{-1}\right)$ of rice varieties at different growth intervals as influenced by different irrigation regimes

\begin{tabular}{|c|c|c|c|c|c|c|}
\hline \multirow[t]{2}{*}{ Treatment } & \multicolumn{6}{|c|}{$\mathrm{N}$ uptake $\left(\mathrm{kg} \mathrm{ha}^{-1}\right)$} \\
\hline & 30 DAT & 60 DAT & 90 DAT & & t Harve & \\
\hline \multicolumn{4}{|l|}{ Main plot (Irrigation regimes) } & Grain & Straw & Total \\
\hline $\begin{array}{l}\mathrm{I}_{1}: \text { AWDI of } 5 \mathrm{~cm} \text {, when water level falls below } 5 \\
\mathrm{~cm} \text { from soil surface in perforated pipe. }\end{array}$ & 5.2 & 33.1 & 88.0 & 48.0 & 41.6 & 89.6 \\
\hline $\begin{array}{l}\mathrm{I}_{2} \text { : AWDI of } 5 \mathrm{~cm} \text {, one day after disappearance of } \\
\text { ponded water on the surface of the soil. }\end{array}$ & 5.7 & 35.0 & 103.0 & 49.6 & 53.3 & 102.9 \\
\hline $\begin{array}{l}\text { I3: Recommended submergence of } 2-5 \mathrm{~cm} \text { water } \\
\text { level as per crop stage. }\end{array}$ & 6.0 & 37.6 & 113.2 & 51.1 & 62.1 & 113.2 \\
\hline SEm \pm & 0.2 & 0.8 & 2.4 & 0.5 & 1.6 & 1.8 \\
\hline C.D $(\bar{P}=0.05)$ & NS & 3.0 & 9.3 & 1.9 & 6.4 & 6.9 \\
\hline \multicolumn{7}{|l|}{ Sub plot (Varieties) } \\
\hline V $_{1}-$ RNR 15048 (Telangana Sona) & 4.8 & 31.8 & 94.4 & 47.0 & 48.7 & 95.7 \\
\hline V $_{2}-$ KNM 118 (Kunaram Sannalu) & 5.5 & 35.5 & 101.4 & 51.2 & 50.8 & 101.9 \\
\hline V $_{3}-$ JGL 18047 (Bathukamma) & 5.8 & 36.8 & 107.9 & 53.2 & 55.7 & 108.8 \\
\hline V $_{4}-$ WGL 283 (Sheethal) & 6.4 & 36.9 & 101.8 & 46.9 & 54.3 & 101.2 \\
\hline SEm \pm & 0.2 & 0.7 & 2.1 & 0.7 & 1.3 & 1.1 \\
\hline C.D $(\mathbf{P}=\mathbf{0 . 0 5})$ & 0.7 & 2.0 & 6.2 & 2.2 & 3.8 & 3.3 \\
\hline \multicolumn{7}{|l|}{ Interaction } \\
\hline \multicolumn{7}{|l|}{ Rice varieties at same level of Irrigation regimes } \\
\hline SEm \pm & 0.4 & 1.2 & 3.6 & 1.3 & 2.2 & 1.9 \\
\hline C.D $(\bar{P}=0.05)$ & NS & NS & NS & NS & NS & 5.8 \\
\hline \multicolumn{7}{|c|}{ Irrigation regimes at same or different levels of rice varieties } \\
\hline SEm \pm & 0.4 & 1.3 & 3.9 & 1.2 & 2.5 & 2.4 \\
\hline C.D $(\bar{P}=0.05)$ & NS & NS & NS & NS & NS & 8.5 \\
\hline
\end{tabular}

DAT: Days after Transplanting, AWDI: Alternate wetting and drying irrigation NS: Non Significant 
Table.3 Interaction effect of rice varieties and different irrigation regimes on Nitrogen uptake $\left(\mathrm{kg} \mathrm{ha}^{-1}\right)$ at harvest

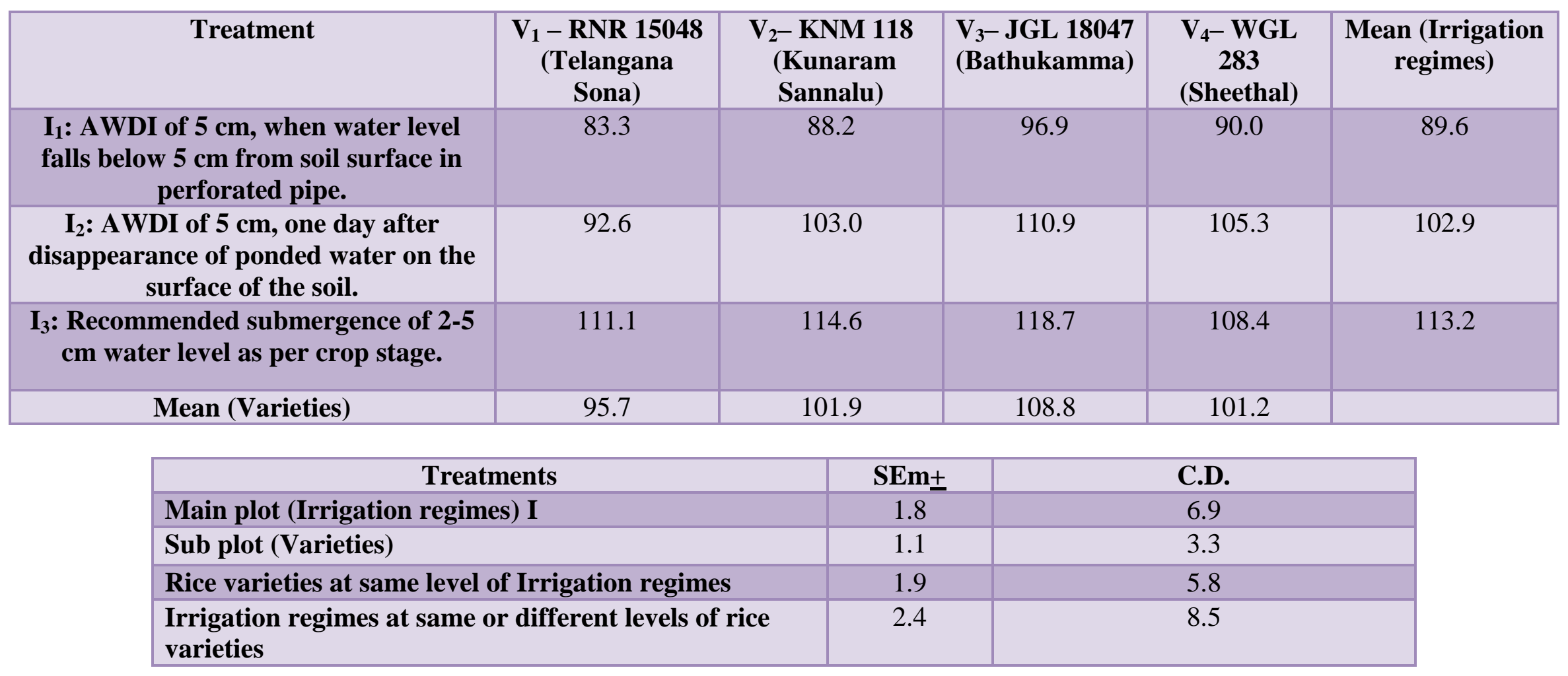


Table.4 Phosphorus uptake $\left(\mathrm{kg} \mathrm{ha}^{-1}\right)$ of rice varieties at different growth intervals as influenced by irrigation regimes

\begin{tabular}{|c|c|c|c|c|c|c|}
\hline \multirow[t]{2}{*}{ Treatment } & \multicolumn{6}{|c|}{ P uptake $\left(\mathrm{kg} \mathrm{ha}^{-1}\right)$} \\
\hline & 30 DAT & 60 DAT & 90 DAT & \multicolumn{3}{|c|}{ At Harvest } \\
\hline \multicolumn{4}{|l|}{ Main plot- (Irrigation regimes) } & Grain & Straw & Total \\
\hline $\begin{array}{l}\mathbf{I}_{1}: \text { AWDI of } 5 \mathrm{~cm} \text {, when water level falls below } 5 \\
\mathrm{~cm} \text { from soil surface in perforated pipe. }\end{array}$ & 3.95 & 10.40 & 14.22 & 15.17 & 12.04 & 27.21 \\
\hline $\begin{array}{l}\text { I }_{2} \text { : AWDI of } 5 \mathrm{~cm} \text {, one day after disappearance of } \\
\text { ponded water on the surface of the soil. }\end{array}$ & 4.06 & 11.00 & 15.94 & 15.15 & 15.60 & 30.75 \\
\hline $\begin{array}{l}\text { I }_{3} \text { : Recommended submergence of } 2-5 \mathrm{~cm} \text { water } \\
\text { level as per crop stage. }\end{array}$ & 4.54 & 10.45 & 18.68 & 17.36 & 17.78 & 35.13 \\
\hline SEm \pm & 0.29 & 0.17 & 1.06 & 0.45 & 0.64 & 0.29 \\
\hline C.D $(P=0.05)$ & NS & $\mathrm{NS}$ & NS & 1.75 & 2.52 & 1.13 \\
\hline \multicolumn{7}{|l|}{ Sub plot- (Varieties) } \\
\hline V $_{1}-$ RNR 15048 (Telangana Sona) & 3.15 & 9.25 & 12.87 & 14.52 & 13.55 & 28.07 \\
\hline V $_{2}-$ KNM 118 (Kunaram Sannalu) & 3.73 & 10.89 & 14.52 & 17.95 & 14.25 & 32.20 \\
\hline V $_{3}-$ JGL 18047 (Bathukamma) & 4.78 & 12.15 & 19.83 & 16.75 & 16.30 & 33.04 \\
\hline V $_{4}-$ WGL 283 (Sheethal) & 5.07 & 10.18 & 17.89 & 14.36 & 16.45 & 30.81 \\
\hline SEm \pm & 0.18 & 0.50 & 0.69 & 0.63 & 0.64 & 0.80 \\
\hline C.D $(\mathbf{P}=\mathbf{0 . 0 5})$ & 0.52 & 1.49 & 2.06 & 1.87 & 1.89 & 2.39 \\
\hline \multicolumn{7}{|l|}{ Interaction } \\
\hline \multicolumn{7}{|l|}{ Rice varieties at same level of Irrigation regimes } \\
\hline SEm \pm & 0.30 & 0.87 & 1.20 & 1.09 & 1.10 & 1.39 \\
\hline 7C.D $(P=0.05)$ & NS & NS & NS & NS & NS & NS \\
\hline \multicolumn{7}{|c|}{ Irrigation regimes at same or different levels of rice varieties } \\
\hline SEm \pm & 0.39 & 0.77 & 1.49 & 1.04 & 1.15 & 1.24 \\
\hline C.D $(\bar{P}=0.05)$ & NS & NS & NS & NS & NS & NS \\
\hline
\end{tabular}

DAT: Days after Transplanting, AWDI: Alternate wetting and drying irrigation NS: Non Significant 
Table.5 Potassium uptake $\left(\mathrm{kg} \mathrm{ha}^{-1}\right)$ of rice varieties at different growth intervals as influenced by irrigation regimes

\begin{tabular}{|c|c|c|c|c|c|c|}
\hline \multirow[t]{2}{*}{ Treatment } & \multicolumn{6}{|c|}{ K uptake $\left(\mathrm{kg} \mathrm{ha}^{-1}\right)$} \\
\hline & 30 DAT & 60 DAT & 90 DAT & \multicolumn{3}{|c|}{ At Harvest } \\
\hline \multicolumn{4}{|l|}{ Main plot- (Irrigation regimes) } & Grain & Straw & Total \\
\hline $\begin{array}{l}I_{1}: \text { AWDI of } 5 \mathrm{~cm} \text {, when water level falls below } 5 \\
\mathrm{~cm} \text { from soil surface in perforated pipe. }\end{array}$ & 5.32 & 33.53 & 48.14 & 13.37 & 40.80 & 54.17 \\
\hline $\begin{array}{l}\mathrm{I}_{2} \text { : AWDI of } 5 \mathrm{~cm} \text {, one day after disappearance of } \\
\text { ponded water on the surface of the soil. }\end{array}$ & 5.48 & 35.90 & 57.46 & 14.28 & 53.44 & 67.72 \\
\hline $\begin{array}{l}\text { I }_{3} \text { : Recommended submergence of } 2-5 \mathrm{~cm} \text { water } \\
\text { level as per crop stage. }\end{array}$ & 5.96 & 36.47 & 64.75 & 15.98 & 55.18 & 71.16 \\
\hline SEm \pm & 0.23 & 1.24 & 2.03 & 0.66 & 1.89 & 2.05 \\
\hline C.D $(P=0.05)$ & $\mathrm{NS}$ & $\mathrm{NS}$ & 7.96 & 2.59 & 7.42 & 8.06 \\
\hline \multicolumn{7}{|l|}{ Sub plot- (Varieties) } \\
\hline V $_{1}-$ RNR 15048 (Telangana Sona) & 4.42 & 29.69 & 49.82 & 11.92 & 44.13 & 56.05 \\
\hline V $_{2}-$ KNM 118 (Kunaram Sannalu) & 5.85 & 41.38 & 61.21 & 16.97 & 51.05 & 68.03 \\
\hline V $_{3}-$ JGL 18047 (Bathukamma) & 5.83 & 34.84 & 58.64 & 14.94 & 54.94 & 69.88 \\
\hline V $_{4}-$ WGL 283 (Sheethal) & 6.23 & 35.29 & 57.47 & 14.35 & 49.10 & 63.45 \\
\hline SEm \pm & 0.21 & 1.07 & 2.11 & 0.91 & 1.79 & 1.78 \\
\hline C.D $(P=0.05)$ & 0.61 & 3.18 & 6.28 & 2.69 & 5.31 & 5.29 \\
\hline \multicolumn{7}{|l|}{ Interaction } \\
\hline \multicolumn{7}{|l|}{ Rice varieties at same level of Irrigation regimes } \\
\hline SEm \pm & 0.36 & 1.86 & 3.66 & 1.57 & 3.10 & 3.08 \\
\hline C.D $(\bar{P}=0.05)$ & NS & NS & NS & NS & $\mathrm{NS}$ & NS \\
\hline \multicolumn{7}{|c|}{ Irrigation regimes at same or different levels of rice varieties } \\
\hline SEm \pm & 0.38 & 2.03 & 3.76 & 1.51 & 3.28 & 3.37 \\
\hline C.D $(P=0.05)$ & NS & NS & NS & NS & NS & NS \\
\hline
\end{tabular}

DAT: Days after Transplanting, AWDI: Alternate wetting and drying irrigation NS: Non Significant 
Fig.1 Dry matter $\mathrm{kg} \mathrm{m}^{-2}$ of rice varieties as influenced by different irrigation regimes

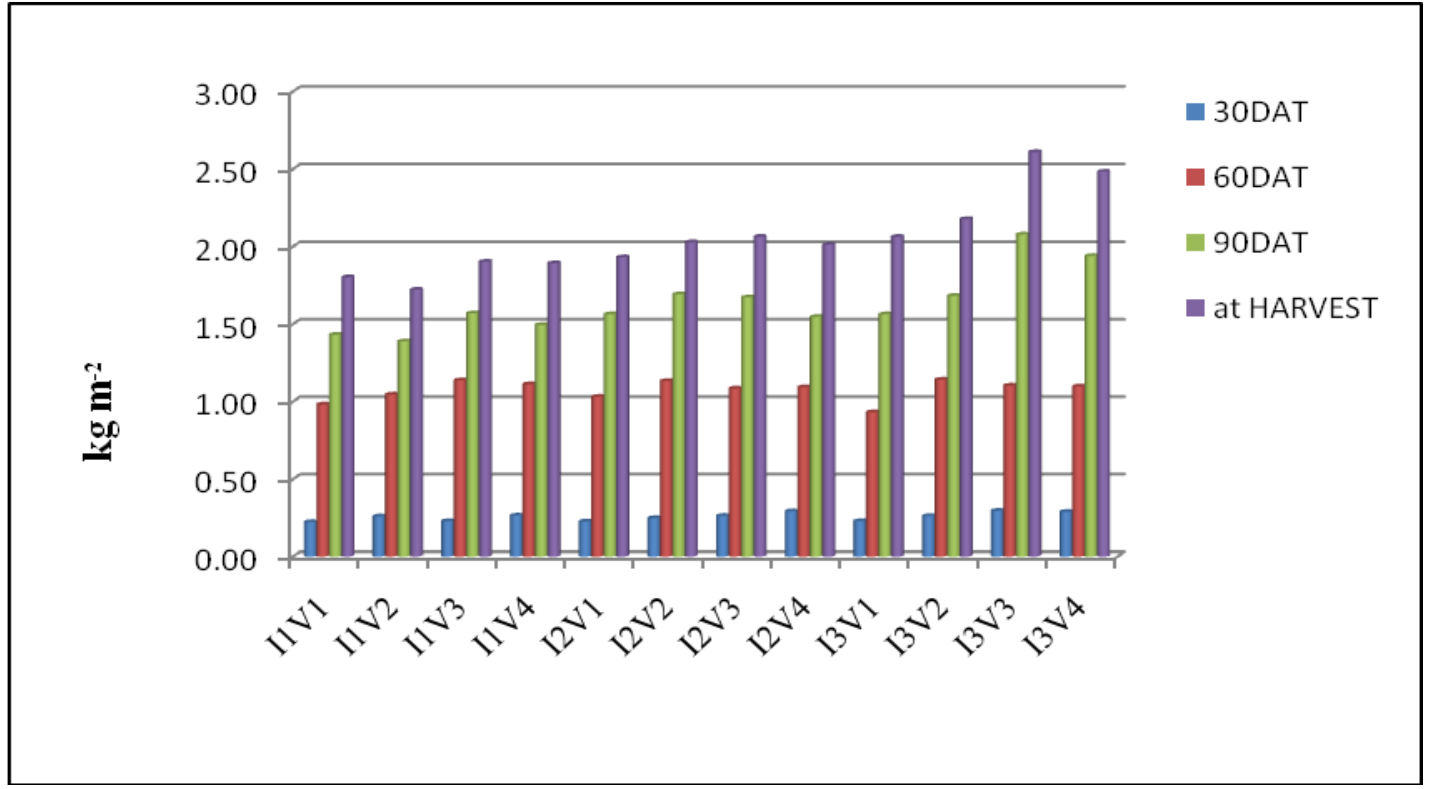

Recommended submergence of $2-5 \mathrm{~cm}$ water level as per crop stage $\left(\mathrm{I}_{3}\right)$ recorded significantly higher $\mathrm{P}$ uptake $\left(17.78 \mathrm{~kg} \mathrm{ha}^{-1}\right)$ than AWDI of $5 \mathrm{~cm}$ irrigation when water level falls $5 \mathrm{~cm}$ below $\left(\mathrm{I}_{1}\right)$ in the field water tube $\left(12.04 \mathrm{~kg} \mathrm{ha}^{-1}\right)$ and was on par with AWDI of $5 \mathrm{~cm}$ at one day after disappearance $\left(\mathrm{I}_{2}\right)$ of ponded water $\left(15.60 \mathrm{~kg} \mathrm{ha}^{-1}\right)$ in straw at harvest. Significantly lower P uptake were obtained with AWDI of $5 \mathrm{~cm}$ submergence water level falls $5 \mathrm{~cm}$ below in the field water tube $\left(\mathrm{I}_{1}\right)$ in straw and total at harvest due to significantly lower dry matter production and less root volume as compared to other treatments. Higher phosphorus accumulation under at recommended submergence of 2-5 $\mathrm{cm}$ water level as per crop stage $\left(\mathrm{I}_{3}\right)$ compared to irrigation of $5 \mathrm{~cm}$, when water level falls below $5 \mathrm{~cm}$ from soil surface in field water tube is ascribed to greater and healthy root growth, increased availability and efficient absorption from the soil and transport of nutrient from roots to shoots and grains, which ultimately improved growth and yield. These results are in agreement with the findings of Ramakrishna (2007) and Chowdhury (2014).
Among the varieties, Sheethal (5.07, 17.89 and $16.45 \mathrm{~kg} \mathrm{ha}^{-1}$ respectively) and Bathukamma $\left(4.78,19.83\right.$ and $16.30 \mathrm{~kg} \mathrm{ha}^{-1}$ respectively) were on par in uptake of $\mathrm{P}$ and were significantly higher than Kunaram Sannalu (3.73, 14.52 and $14.25 \mathrm{~kg} \mathrm{ha}^{-1}$ respectively) and Telangana Sona (3.15, 12.87 and $13.55 \mathrm{~kg} \mathrm{ha}^{-1}$ respectively) at 30 and 90 DAT by straw at harvest. P uptake by Bathukamma (12.15 Kg ha ${ }^{-1}$ ) was at $60 \mathrm{DAT}$ was significantly higher than rest of the varieties and Telangana Sona recorded significantly lower $\mathrm{P}$ uptake the other varieties except Sheethal. However, rice varieties Kunaram Sannalu and Telangana Sona were at par P uptake at 90 DAT, P uptake and significantly lower than Bathukamma (19.83 kg ha $\mathrm{kg}^{-1}$ and Sheethal $\left(17.89 \mathrm{~kg} \mathrm{ha}^{-1}\right)$. Bathukamma (16.75 kg ha $\left.{ }^{-1}\right)$ and Kunaram Sonnalu (17.95 kg ha $\left.{ }^{-1}\right)$ were on par and significantly higher than Sheethal $\left(14.36 \mathrm{~kg} \mathrm{ha}^{-1}\right)$ and Telangana Sona $(14.52 \mathrm{~kg}$ $\mathrm{ha}^{-1}$ ) in uptake of $\mathrm{P}$ by grain at harvest. However P uptake of Kunaram Sannalu by grain in Sheethal and Telangana Sona were on par to each other at harvest. At harvest in total $\mathrm{P}$ uptake of Bathukamma (33.04 $\left.\mathrm{kg} \mathrm{ha}^{-1}\right)$, 
Kunaram Sannalu (32.02 $\left.\mathrm{kg} \quad \mathrm{ha}^{-1}\right)$ and Sheethal (30.81 kg ha-1) were on par and recorded significantly higher than Telangana Sona (28.07 kg ha ${ }^{-1}$ ). Significantly lower P uptake was obtained with Telangana Sona at different crop periods and at harvest might be due to genetically inherent character of the variety to produce lower dry matter production there by lower uptake of nutrients.

\section{Potassium uptake}

Uptake of $\mathrm{K}$ was not significantly influenced by the interaction effect between different rice varieties and irrigation regimes (Table 5).

Different irrigation regimes significantly influenced uptake of $\mathrm{K}$ at all stages except at 30 and 60 DAT (Table 5) and recommended submergence of $2-5 \mathrm{~cm}$ water level as per crop stage $\left(\mathrm{I}_{3}\right)$ recorded on par $\mathrm{K}$ uptake $\left(64.75,15.98,55.18\right.$ and $\left.71.16 \mathrm{~kg} \mathrm{ha}^{-1}\right)$ with AWDI of $5 \mathrm{~cm}$ at one day after disappearance of ponded water $\left(\mathrm{I}_{2}, 57.46,14.28,53.44\right.$ and $67.72 \mathrm{~kg} \mathrm{ha}^{-1}$ ) at 90 DAT and by grain, straw and total at harvest and were significantly higher than AWDI of $5 \mathrm{~cm}$ irrigation when water level falls $5 \mathrm{~cm}$ below in the field water tube $\left(\mathrm{I}_{1}, 48.14,13.37,40.80\right.$ and 54.17 $\mathrm{kg} \mathrm{ha}^{-1}$ ) except by grain at harvest.

Significantly lower K uptake were obtained with AWDI of $5 \mathrm{~cm}$ submergence when water level falls $5 \mathrm{~cm}\left(\mathrm{I}_{1}\right)$ below surface in the field water tube $(48.14,13.37,40.80$ and $54.17 \mathrm{~kg}$ $\mathrm{ha}^{-1}$ ) at 90 DAT and by grain, straw and total at harvest than rest of the treatment except it was on par with the AWDI of $5 \mathrm{~cm}$ at one day after disappearance $\left(\mathrm{I}_{2}\right)$ of ponded water in grain at harvest. The lowest uptake by irrigation of $5 \mathrm{~cm}$, when water level falls below $5 \mathrm{~cm}$ from soil surface in field water tube treatment was might be due to the affect some physiological processes such as transpiration rate which would decrease plant K uptake under water stress condition. Similar results were reported by Ramakrishna (2007) and Chowdhury (2014).

Among the varieties, Bathukamma (5.83, 58.64, 14.94 and $69.88 \mathrm{~kg} \mathrm{ha}^{-1}$ respectively), Kunaram Sannalu (5.85, 61.21, 16.97 and $68.03 \mathrm{~kg} \mathrm{ha}^{-1}$ respectively) and Sheethal (6.23, 57.47, 14.35 and $63.45 \mathrm{~kg} \mathrm{ha}^{-1}$ respectively) were on par and recorded significantly higher $\mathrm{K}$ uptake than Telangana Sona $\left(4.42,49.82,11.92\right.$ and $56.05 \mathrm{~kg} \mathrm{ha}^{-1}$ respectively) at 30, 90 DAT and grain and total at harvest (except by grain at harvest). At 60 DAT, Kunaram Sannalu (41.38 $\mathrm{kg} \mathrm{ha}^{-1}$ ) recorded significantly higher $K$ uptake than Sheethal, Bathukamma and Telangana Sona. However, Sheethal and Bathukamma were at par to eachother in $\mathrm{K}$ uptake of with straw Bathukamma (54.94 kg ha ${ }^{-1}$ ) was on par with Kunaram Sannalu (57.05 kg ha $\left.{ }^{-1}\right)$ and significantly higher than Sheethal $(49.10 \mathrm{~kg}$ $\mathrm{ha}^{-1}$ ) and Telangana Sona (44.13 $\left.\mathrm{kg} \mathrm{ha}^{-1}\right)$. However Kunaram Sannalu and Sheethal, were at par to each other in uptake of $\mathrm{K}$ by straw at harvest. Significantly lower K uptake was obtained at Telangana Sona at different stages and at harvest compared to other varieties and it might be due to lower dry matter production of the variety.

It can be concluded that recommended submergence of $2-5 \mathrm{~cm}$ water level as per crop stage recorded higher dry matter and $\mathrm{N}$, $\mathrm{P}$ and $\mathrm{K}$ uptake over AWDI of $5 \mathrm{~cm}$ when water falls below $5 \mathrm{~cm}$ from soil surface in field water tube and was on par with AWDI of $5 \mathrm{~cm}$ at one DADSW. Bathukamma produced higher drymatter and N P K uptake compared to Kunaram Sannalu, Sheethal and Telangana Sona.

\section{References}

Aggarwal, P.K., Bandyopadhyay, S.K., Pathak, H., Kalra, N., Chander, S and Kumar, S. 2000. Analysis of yield 
trends of the rice-wheat system in northwestern India.

Outlook Agriculture., 29:259-268.

Arif, C., Setiawan, B.I., Mizoguchi, M and Doi, R. 2012. Estimation of water balance components in paddy fields under non-flooded irrigation regimes by using

excel solver. Journal of Agronomy. 11(2): 53-59.

Arora, V. K. 2006. "Application of a rice growth and water balance model in an irrigated semi-arid subtropical environment," Agricultural Water Management, vol. 83, no. 1-2, pp. 5157.

Bouman, B.A.M and Tuong, T.P. 2001. Field water management to save water and increase its productivity in irrigated lowland rice. Agricultural Water Management. 49, pp. 11 -30.

Chowdhury, M. R., Kumar, V., Sattar, A and Brahmachari, K. 2014. Studies on the water use efficiency and nutrient uptake by rice under System of Intensification. The Bioscan. 9 (1): 85-88.

Guerra, L. C., Bhuiyan, S. I., Tuong,T. P and R. Barker. 1998. Producing More Rice with Less Water from Irrigated Systems. SWIM Paper 5, IWMI/IRRI, Colombo, Sri Lanka. pp 24.

Kumar, S., Singh, R. S and Kumar, K. 2014. Yield and nutrient uptake of transplanted rice (Oryza sativa) with different moisture regimes and integrated nutrient supply. Current Advances in Agricultural Sciences. 6
(1): 64-66.

Maclean, J. L., Dawe, C., Hardy, B and Hettel, G. P. Rice Almanac, 2002. International Rice Research Institute, Los Banos, Philippines,3rd edition, pp 253.

Panda, S. C., Rath, B. S., Tripathy, R. K and Dash, B. 1997. Effect of water management practices on yield and nutrient uptake in the dry season rice. Oryza. 34: 51-53.

Ramakrishna, Y., Singh, S and Parihar, S.S. 2007. Influence of irrigation regime and nitrogen management on productivity, nitrogen uptake and water use by rice (Oryza sativa). Indian Journal of Agronomy. 52 (2): 102-106.

Tao, F., M., Yokozawa, Z., Zhang, Y., Hayashi, H. G and Fu, C. 2004. Variability in climatology and agricultural production in China in association with the East Asia summer monsoon and El Niño South Oscillation. Climate Research. 28: 2330.

Tuong T. P and Bouman, B. A. M. 2002. "Rice production in waterscarce environments," in Water Productivity in Agriculture: Limits and Opportunities for Improvement, J. W.

Kijne, R. Barker, and D. Molden, Eds., vol. 1 of The Comprehensive Assessment ofWater Management in Agriculture Series, pp. 13-42, CABI, Wallingford, UK.

\section{How to cite this article:}

Sharath Chandra, M., K. Avil Kumar, M. Madhavi and Srinivasa Chary, D. 2019. Dry Matter Production and Nutrient Uptake of Rice (Oryza sativa L.) Varieties under Alternate Wetting and Drying in Puddled Soil. Int.J.Curr.Microbiol.App.Sci. 8(08): 2302-2313. doi: https://doi.org/10.20546/ijcmas.2019.808.267 